\title{
Valeria Sergueenkova, Felipe Rojas. "Persian on their Minds : Achaemenid Memory Horizons in Roman Anatolia"
}

\section{Olivia Ramble}

\section{(2) OpenEdition Journals}

Édition électronique

URL : http://journals.openedition.org/abstractairanica/49841

DOI : 10.4000/abstractairanica.49841

ISBN : 1961-960X

ISSN : 1961-960X

Éditeur :

CNRS (UMR 7528 Mondes iraniens et indiens), Éditions de l'IFRI

\section{Référence électronique}

Olivia Ramble, « Valeria Sergueenkova, Felipe Rojas. "Persian on their Minds : Achaemenid Memory

Horizons in Roman Anatolia" », Abstracta Iranica [En ligne], Volume 40-41 | 2019, document 15, mis en ligne le 30 décembre 2019, consulté le 27 avril 2021. URL : http://journals.openedition.org/

abstractairanica/49841; DOI : https://doi.org/10.4000/abstractairanica.49841

Ce document a été généré automatiquement le 27 avril 2021.

Tous droits réservés 


\title{
Valeria Sergueenkova, Felipe Rojas. "Persian on their Minds : Achaemenid Memory Horizons in Roman Anatolia"
}

\author{
Olivia Ramble
}

\section{RÉFÉRENCE}

Valeria Sergueenkova, Felipe Rojas, "Persian on their Minds : Achaemenid Memory Horizons in Roman Anatolia" in Rolf Strootman, Miguel John Versluys (eds.).

Persianism in Antiquity. Stuttgart : Franz Steiner, 2017, p. 269-288 (Oriens et Occidens

25)

1 Les A. montrent que la revendication - voire la mise en scène - de leur passé perse par les villes de l'Anatolie romaine n'est pas un acte de défi envers Rome : elle témoigne plutôt du prestige de l'empire achéménide sous Auguste et ses successeurs, et de l'autorité que conservaient ses décisions administratives. L'analyse s'articule autour de trois "stratégies" de revendication : l'invocation de documents achéménides réinscris ou forgés - par les ambassadeurs des provinces asiatiques pour appuyer une demande auprès du sénat ; la représentation publique de rituels (pseudos-)zoroastriens et autres cérémonies "perses »; la toponymie. Ces démonstrations sont d'abord à comprendre dans le contexte de rivalités locales, où l'héritage perse permettait de se démarquer et de prétendre à un illustre passé. Surtout, on aurait tort de concevoir « la Perse » et « Rome » comme des entités antithétiques : aussi bien pour les aristocrates provinciaux que pour les dignitaires romains, elles étaient des manifestations successives d'un pouvoir impérial, dont la légitimité et l'autorité se confirmaient l'une l'autre. Les sites " perses » étaient d'ailleurs souvent eux-mêmes des sites réappropriés par les Achéménides et dont l'importance cultuelle était ancienne, car ses différents 
passés coexistaient et pouvaient être invoqués avec fierté et sans contradiction par les habitants de l'Anatolie.

\section{AUTEURS}

\section{OLIVIA RAMBLE}

Doctorante EPHE, Mondes iranien et indien, Paris 